\title{
Teaching and testing of English listening and speaking in secondary schools in Nepal: Pretend for praxis?
}

\author{
Kesh Rana \\ Faculty of Educational Sciences, University of Oslo, Norway \\ Karna Rana \\ Faculty of Social Sciences and Education, Nepal Open University \\ \& GraminAdarsha Multiple Campus, Kathmandu, Nepal
}

\begin{abstract}
Secondary English course requires testing of four skills: listening, speaking, reading and writing independently. Secondary Education Examination (SEE) board conducts a written examination, which includes reading and writing skills, through different centres and English teachers are responsible to test students' listening and speaking testsin their own schools and submit grades to District Education Office. Semi-structured interviews with secondary English teachers in private schools and school graduates investigated how the teacherspractise listening and speaking skills in the classrooms and administeraural-oral tests. Findings indicate that private schools in the capital city have mandated Englishonly for communication in school premises with an expectation to develop students' English language proficiency. Teachers focused on centre-based written examination and less emphasised the teaching and testing of listening andspeaking skills. Teachers' random assessment of students' aural-oral skills without formal tests supported in declining the teaching of these skills. This article suggests that for realising the examination effective, sustainable system needs to be developed for teachers to teach all language skills equitably.
\end{abstract}

Keywords: English;teaching; listening; speaking; testing

\section{Introduction}

English is one of the compulsory subjects in the school curriculum in Nepal. Children from Grade One begin to learn the English language as a subject and they continue this course throughout their school life. This subject focuses on the development of students' English language skills: listening, speaking, reading and writing. The course equally emphasises the teaching of language aspects particularly in secondary school. For teaching and learning the course, Curriculum Development Centre (CDC) has designed a coursebook, teachers' guide and other audio-visual materials for 
both students and teachers. Centre for Human Resource and Educational Development (CHRED) provides training to English teachers on how to teach and assess the course. As the course has been designed to enable students to communicate in both written and verbal ways, secondary school students are expected to be able to perform a certain level of English language competence in both forms. Teachers teaching the course are expected to develop secondary students' expected skills in the completion of the course.

Secondary Education Examination (SEE) board has developed criteria for testing students' English language skills and the system requires students to sit both written and oral exams. A written exam that covers reading and writing skills is allocated 75 marks and practical exam that covers listening and speaking skills is allocated 25. The SEE board manages both written and oral examinations throughout the country (Curriculum Development Centre, 2016). Testing of listening and speaking skills systematically started in 2000 (2057 BS) (Santwona Memorial Academy, 2013). However, although the national curriculum emphasises the teaching of all four skills equally and the testing of them systematically, listening and speaking skills are, at some level, ignored by central examination board (Dawadi, 2018). Dawadi (2018) reported that in the early years the testing system of listening and speaking skills was functional when the SEE board (previously known as School Leaving Certificate Examination Board prior to 2014) effectively managed overall examination through its bodies such as District Education Office and exam centres by appointing qualified teachers to conduct both listening and speakingtests in each examination centre. However, the testing of listening and speaking skills of students has been criticised in recent years, particularly since the examination board allowed secondary schools to conduct tests and to allocate marks themselves in 2014. This study examined how listening and speaking tests of English subject in secondary school are conducted in the board exam. This article reports on how secondary English teachers and students perceive and practise listening and speaking tests. This article also reports on secondary school graduates' experiences of the tests.

\section{English language in secondary education}

The teaching of the English language started in Nepal with the establishment of Durbar High School in 1854 for the children of Rana and royal families (Shrestha, Pahari \& Awasti, 2014). In 1903, the school was opened for public and other than royal family children also got the opportunity to learn the English language including other subjects such as Mathematics and Nepali(Bista, 2011). Gradually several schools across the country started to educate members of the public. When Chandra Shamsher Rana, the Prime Minister of Nepal, established Tri-Chandra College, the first higher education institution in the country, in 1918, many school graduates, primarily the graduates of Durbar High School, got an opportunity to get higher education degree in home country(Eagle, 1999).

With the establishment of democracy in 1951, several hundred schools were established across the country. Gradually in 1971 (2028 BS), National Education System 
Plan (NESP) organisedall schools in a system and national education curriculum unified and uniformed all schools (Ministry of Education, 1971). National Education System Plan, 1971 (2028 BS) mandated English as a subject to be taught in schools in Nepal. With the implementation of the National Education System Plan, 1971 (2028 $B S)$, the teaching of English language in secondary school increased interest and stress in both teachers and students. However, the influence of global changes in Nepal increased the demand for the English language in the 1990s (Dawadi, 2018). Rana (2018) argues that the privatisation of education after the reestablishment of democracy in 1991 promoted the teaching of English language particularly in private schools and colleges, and its influence was gradually observed in government schools in the early new millennium as many government schools shifted from Nepali to English medium. Among 35601 schools in the country, there are 29035 government schools and 6566 private schools (Ministry of Education Science and Technology, 2018). The private schools claim that they use English as a medium of instruction (EMI) in their classroom teaching. Several studies (Khati, 2013; Phyak, 2011; Rana, 2018) reported that many government schools throughout the country have shifted from Nepali to English with the expectation of improving the quality of education. However, it is a debatable issue whether or not the schools in multilingual communities in Nepal have been able to improve their educational qualities.

Some studies (Giri, 2009; Khati, 2013; Phyak, 2011; Rana, 2018) reported that in absence of clear language policy in Nepal, many indigenous languages including Nepali, the national language, among 123 are under threat and influenced by foreign languages particularly the English. Although Nepal's Constitution, 2015 clearly states that children have right to education in their mother tongue especially in primary and intermediate levels (Government of Nepal, 2015), the national education system is based on Nepali, the only national language and English excluding few exceptional primary schools who teach in the mother tongue. However, Rana (2018) argues that fragile language policy has allowed several foreign languages, particularly the English, to flourish in linguistically diverse communities of Nepal. Giri (2011) worries that the rapid development and high acceptance of the English language in Nepal's education is gradually building wider space in Nepal and that the English as a foreign language may get second language status soon. Khati (2011) argues that private schools have been able to attract the public's interest and increase their English language business even in small towns. Moreover, Aryal, Short, Fan and Kember (2016)argue thatparents send their children to English medium schools for mainly three reasons: English is a matter of social prestige for them, it is a key to open a wide range of job opportunities in their children's future, and it opens door to abroad studies. Duwadi (2018) opines that the use of English language and English teaching in Nepal will further grow with the migration of youthsto different parts of the world for further education and employment.

\section{The teaching of English listening and speaking skills}

There were different notions of the teaching of speaking and listening skills before the 
introduction of communicative teaching approach in the 1980s (Richards, 2006). Teaching was particularly based on sentence production or grammar in the 1970s followed the reproduction of sentences that the teachers used to lead the memorization of texts (ibid). However, the notion was changed when the communicative approach was adopted in teaching foreign languages. The new approach suggests that teachers' role of teaching a foreign or second language is context-sensitive and, therefore, English teacher needs to understand the environment for teaching the English language to non-native learners (Broughton, Brumfit, Flavell, Hill \& Pincas, 2003). Vandergrift and Goh (2012) argue that, although the teaching of all skills: listening, speaking, reading and writing is equally important for non-native speakers, particularly approaches to listening skills is often ignored and learners are expected to develop their listening skill on their own. They suggest that a second or foreign language teacher needs to be competent enough to teach the listening skill to learners and to develop students' language proficiency. Alonso (2012) argues that opportunities for learners to practise listening and speaking in a real-life situation is significant for developing their English proficiency.Tavil's (2010) study in Turkey suggested that teachers need to allow learners to have a natural conversation to develop their both listening and speaking skills as they are integrated and practical. Zhang (2009) argues that, although people prioritise speaking against listening and consider listening as a passive skill, listening to someone actually is an active skill which is inseparable from speaking.Bozorgian's(2012)study in Iran found that the teaching of listening skill significantly improved students' speaking skill and vice versa.

For the development of listening and speaking skills, Santwona Memorial Academy (2013)suggests that enough time and authentic materials can help nonnative English learners develop their native-like language. However, they argue that teachers' capacity of English language and knowledge of teaching strategies can play a significant role in students' learning of the language. In schools particularly in developing countries including Nepal, it is questionable why or not listening and speaking skills are taught. For example, Shrestha (2018)explains that the reformed secondary board examination system has mandated the testing of students' listening and speaking skills of the English language for mainly political, economic and educational reasons, and this system demanded the teaching of all skills: listening, speaking, reading and writing. He argues that the government executes such changes to show own power or because of international vested interest, to prepare youths for global job opportunities and to meet the regional or international standard of education. However, a study (Santwona Memorial Academy, 2013) reported that the majority of secondary English teachers ignore listening and speaking skills in their classroom teaching although the examination requires testing of those skills.

\section{Assessment of listening and speaking skills}

The Secondary Education Examination (SEE) board prepares, manages and controls final board examination including publication of result (Curriculum Development Centre, 2016). The SEE board, 
previously known as School Leaving Certificate (SLC) board since its establishment in Nepal in 1934 (1991 BS), has reformed assessment systems of English language course several times including the letter grading in 2014. The SLC examination board included listening and speaking skills of English in test system in 2000 (2057 BS) and the examination centres employed secondary English teachers to conduct the test (Santwona Memorial Academy, 2013). However, Santwona Memorial Academy (2013) reported that testing of listening and speaking was found random and it was becoming a formality. The situation may be similar in other developing countries such as Bangladesh, India and Pakistan where English is taught as a foreign or second language. Sultana (2018) doubts the validity of secondary school English examination in Bangladesh which ignores listening and speaking skills. Eng, Mohamed and Javed (2013) argued that, although the teaching of listening skill in Pakistan's secondary schools significantly improved students' speaking and other skills, secondary school examination emphasised written examination by ignoring listening and speaking skills of the English language. Similarly, Ahmad and Agarwal (2018) observed that many other secondary certificate examination boards in some states in India still ignore teaching and testing of listening and speaking skillsdespite the Central Board of Secondary Education (CBSE) in India, after piloting the assessment of speaking and listening (ASL) in 120 schools in 2012, formally implemented the revised ASL system in Classes 9, 10 and 11 in its affiliated schools across the world.

Many studies (Bozorgian, 2012; Liu, 2009; Ramanathan, 2008; Rubin, Daly,
McCroskey \& Mead, 1982; Sultana, 2018) reported that listening skill is often ignored in the language classroom. However, others (Khamkhien, 2010; Liu, 2009) argue that there are many reasons, such as the use of local and national languages in the English language classroom, educational policy of the country and school environment, which influence teaching and learning of foreign languages including the English. Moreover, Liu (2009) emphasises that the availability of teaching and learning materials for English teachers and students increase students' performance.

Dawadi's (2018) interviews with English teachers in Nepal investigated that the testing of listening and speaking skills in examinations had a strong connection with their motivation for learning the English language. She reported that students were less anxious about listening and speaking tests than reading and writing exams in a centre because students' own teachers assessed their listening and speaking skills in school. Rubin et al. (1982) suggest that well-managed assessment practice can have a desirable effect on teachers' instructional activities and test achievements can have a progressive function in students' learning. They emphasise that the alignment between examinations and educational practice can ease the testing of students' learning and their sincere participation in teachers' instructional activities. However, Choi (2008) argues that most of the Asian countries' English education is test-oriented instead of developing learner's language skills and that listening skill in secondary education in the countries including Taiwan, which is ignored in exams, has a limited connection with teaching and learning the English language in the classroom. 


\section{Research design}

As a qualitative interpretive design, this case study followed participants with semistructured interviews. The documentary analysis provided detailed contextual information and conceptual framework. Following the ideas of Patton (1990) and Bryman (2016), semi-structured interviews explored secondary English teachers' perception, practice and experience of teaching and testing of English listening and speaking skills and secondary school graduates' perception of learning and testing of English listening and speaking skills. For the study, four private English medium secondary schools from different locations of Kathmandu Valley, the capital city of Nepal, were involved. The schools were purposively selected, as suggested by Kumar (1999), as all schools in Kathmandu have access to facilities for teaching and learning and schools in Kathmandu are more likely to be equipped with technologies.

Among the 12 participants involved in this study, 4 participants were secondary English teachers selected from those four high schools representing one from each. The other 8 were secondary school graduates which included 4 recent graduates (whose examination was assessed on the basis of letter grading system, e.g. A+, A, B+B, C+, C, D and D-) and 4 earlier graduates (whose examination was assessed on the basis of numbering, e.g. 70, 75, 80 and 85). Teachers and students volunteered to become involved in this study and they are represented by pseudonyms in order to maintain their confidentiality and anonymity.

The research explored the participant teachers' experiences and perception of the teaching and testing of English listening and speaking skills and students' experience and perception of learning the skills and testing of them in board exam(Creswell, 2002) in natural settings(Anderson \& Arsenault, 2005). Additionally, this research design helpedunderstand how participants interpreted their experiences, how they constructed their world, and what meaning they attributed to their experiences(Merriam \& Tisdell, 2016).

Interpretive phenomenological analysis, as suggested by Smith and Osborn (2004), helped stream a wide range of qualitative information gathered through semistructured interviews with several participants, generate key themes and critically analyse the data. Documents were read against the primary data.

\section{Findings}

The study investigated a number of findings related to English as a foreign language teaching in private schools in the capital city of Nepal. The findings, particularly focused on testing of listening and speaking skills, which include English language ruling in schools to develop students' speaking, resourcing English language classrooms, classroom practice of English language and how students' listening and speaking skills are tested.

\section{English language ruling in school}

Documentary analysis and field interviews with teachers and students revealed that the schools, which were private, involved in this study had both Nepali and English languages as medium of instruction in the classroom. However, the findings indicated that the schools emphasised the use of the English language as a means of 
communication in school premises. Moreover, the schools enforced their own law which mandated the use of English for communications and students were penalised for breaching the regulation.

We used English for communication. We had a rule of using English in school. If we didn't speak English, we were fined a certain amount daily. (Shiva)

We including teachers had to speak English to maintain an Englishspeaking environment. But we used to speak mostly Nepali among our friends and just used to speak English in front of the principal and particularly strict teachers. (Diya)

If we didn't use English, we would be punished. But sometimes we used the Nepali language among our friends too. (Manoj)

The majority of students echoed that language regulation to some extent helped them learn and improve their English language and create an English-speaking environment in the school. However, there was no evidence except the live interviews with them, which was not sufficient, to authenticate their voice. Although the teachers interviewed agreed that punishments minimised the use of students' mother tongue and increased English speaking in schools, they were unable to create a completely Englishspeaking environment as expected. They argued that students, who have their own mother tongue, have many challenges of learning English, a distinct language which has its own linguistic features such as pronunciation, stress, accent and structure. For example:
Firstly, teachers teaching English are not native speakers. Secondly, the students happen to use their mother tongue accidentally due to the habit of using their mother tongue at home despite a strict rule at school. (Geeta)

We have English-speaking environment at our school. I know this sort of environment provides speaking exposure for students and helps them speak without hesitation. For maintaining the English-speaking environment, we formulate some rules. For example, students are fined a certain amount per day if they speak Nepali. (Sudhan)

Non-native English speakers may not be able to create a native exposure for students. However, the findings suggested that the attempts for maintaining an English-speaking environment at school can be helpful in the development of students' speaking and listening skills. Nevertheless, the findings suggest a need to further study how the penalty system for breaching English language policy would create an English environment in their schools.

\section{Classroom practice}

The findings suggested that the teaching of English language in Nepali schools requires competent teachers and authentic teaching materials. In order to improve students' listening and speaking skills, they need some practical classes which provide students with opportunities for the actual practice of English listening and speaking. However, the participants in this study argued that listening and speaking skills were less prioritised than reading and writing in the classroom. The interviews 
with students and teachers explored that their schools had limited teaching and learning materials, for example, audio cassette, cassette player and prescribed textbook, and rare classes for practising the skills.

We mostly listened to the cassettes and did textbook exercises. It was sometimes fun to listen to and carry out those activities. But there were rare classes. (Shiva)

So far, I remember, we rarely had classes of listening and speaking. (Ajay)

I don't think we had any particular speaking class but rarely we had listening practice on cassette. (Diya)

We used to read the script instead of listening and do exercises but mostly we skipped them. (Sujal)

The students' responses contradicted with teachers' voices. The majority of students expressed their dissatisfaction against teachers' negligence of teaching listening and speaking skills although they are the primary skills. They also argued that the unsystematic distribution of practicum marks for listening and speaking in the SEE without formal tests decreased the value of teaching the skills. Their responses indicated that the teaching of English in school was much more exam-oriented than students' English language development. In contrast, teachers, for example, Sangam and Geeta, argued that they had English listening and speaking practice in the daily classroom as well as separate practice classes.
The English course focuses on all skills. I conduct listening and speaking classes on a regular basis. However, the materials prescribed by the CDC are not available in the market. We have more classes in reading and writing. I encourage students to read English newspapers and have a mini Oxford English dictionary. (Sangam)

We have practical classes occasionally, but cassettes for listening tasks are not sometimes timely available in the market. In such a situation, I sometimes use other listening materials to boost up students' skill. (Geeta)

Most of the tasks or exercises given in the textbook are skipped. I often involve students in listening tasks prescribed in the book. I play a cassette and the students complete the exercises in two or three classes. (Meena)

Teachers' explanation about the lack of prescribed audio cassette was evident that, although they claimed they had regular or occasional classes of listening and speaking, they would not have enough classes for the practice of these primary skills. Similar to the findings of previous studies (Dawadi, 2018; Santwona Memorial Academy, 2013), teachers gave priority to reading and writing skills for which students had to sit the board exam but the teaching of English listening and speaking was ignored for a reason - perhaps none would care how teachers assessed these skills and graded them without formal tests, which is discussed elsewhere in the following sections. 
Resourcing English language classroom

Both teachers and students in interviews emphasised that their schools would have equipped their classrooms with basic learning materials such as audio-visual materials for practising English speaking and listening. The majority of teachers stated that they had some kind of audiovisual materials for the teaching of listening and speaking skills in their schools. However, they shared their frustration that they were unable to involve students in communicative activities in the classroom for the reason they did not want to share. Only the audio cassette produced by the Curriculum Development Centre was scarce in the market and some of the teachers had to rely on loaned cassette from their colleagues or textbook transcripts.

Once I couldn't find the cassette in the market for listening activities. So, I had to borrow one from another school. (Meena)

We have some technologies in our classes like multimedia projectors but not in all classes. (Sangam)

We use cassettes, cassette players and textbook for exercises. (Shiva)

We have cassettes only. (Ajay)

For the practical exercises of listening and speaking in the textbook, the CDC has produced cassettes or CDs. (Geeta)

The findings suggested that the majority of teachers, although they said they occasionally used audio cassette, were reluctant to speak about using audio-visual materials in their English language teaching. Although they reported that their schools had some level of information and communication technologies (ICTs) and they could access some authentic materials from websites and use such materials to teach listening and speaking skills, none of them confidently said that they used the available digital resources. Instead, the teachers echoed that they advised their students to explore authentic English language materials and use them to improve their English language skills. The interviews with students affirmed that the majority of students utilised homely available resources such as English television channels to improve their English language.

I listen to English music and watch English movies, English programmes and English Premier League. These all help me develop my listening and speaking skills. (Ajay)

I watch English Premier League and Spanish La-Liga. I listen to English music. (Shiva)

I sometimes watch $\mathrm{BBC}$ and $\mathrm{CNN}$ news, WWE and football match. (Manoj)

I listen to English songs. Sometimes I watch English movies too. (Chandra)

Although the teachers had limited English practical classes, their advice to their students seemed to be productive as the students followed the instruction to improve their English language by watching various English television channels at home. 


\section{Requirement and practicality of listening and speaking tests}

Participants explained that the way how the Secondary Education Examination board used to conduct practical tests of students' English listening and speaking skills in examination centres was changed and that schools got the responsibility and submitted test scores to the District Education Office. The teachers commented that they used to sincerely prepare their students for listening and speaking tests when the examination centres used to conduct the tests, and that the test scores had some level of reliability. However, they argued that after the schools got the responsibility of testing students' English listening skills, the testing of the skills would be considered a formality and taken as a granted strategic idea to increase students' overall final grade.

Nowadays, the practical exam of English in the SEE is considered as a means to boost up only student's overall percentage or grades. (Sudhan)

When students had to sit English practical tests in exam centres, both teachers and students used to consider listening and speaking classes an important part of learning. But nowadays, we focus primarily on reading and writing skills. We are directly or indirectly forced to give full marks to all students even if they do not deserve. So, students also ignore listening and speaking skills. (Meena)

I am compelled to provide full marks for each student. The principal wants me to award full marks for everyone. I am telling you the truth. (Ganga)
The teachers including Sudhan, Meena and Ganga tried to protect themselves in the interviews by misrepresenting their teaching role as a follower of school instruction and national examination board system. Nevertheless, they continued emphasising their continuous assessment strategies to motivate students to communicate in English and to improve their speaking and listening skills, although they were unable to explain how they would assess students' aural-oral skills. Their comments to the school principal's force to grant full marks for each student without formal tests of listening and speaking skills raised an issue about SEE practical tests and validity of the qualification. Interviews with SLC graduates who had English listening and speaking tests in board examination centres, and SEE graduates who required to sit the tests in their schools explored that as soon as the new system of examination allowed schools to conduct practical tests of English, the freedom for schools and teachers resulted in teachers' deliberate negligence of teaching full course of English, students' declining interest of English practical activities and issues of assessment.

We had the practical exam of English listening and speaking in the board exam at our own school, but I think it was not taken seriously. (Ajay)

We were never informed listening and speaking, reading and writing are equally important. We did reading and writing activities of the textbook, so we thought learning English is only the learning of reading and writing skills. (Shiva) 
I think we all got 25 marks out of 25 in English practical, but we didn't sit any tests. It was the same case in all subjects like Science, Account. This is not good. Marks should be based on our performance. (Chandra)

The majority of students echoed that their English teachers graded their listening and speaking skills without a formal test and that the students found their score highest possible in all practical courses. Moreover, they expressed their dissatisfaction against random assessment system which did not reflect their real performance of English language skills. However, one of the SLC graduates who had her English practical tests in the exam centre shared her dissatisfaction against her English score although she had high score near about full marks.

The moment I got just 23 marks in the practical exam. If I got 24 out of 25 in the practical exam, I would get a distinction division. I was one of the good students in my class. I know I would get the full marks in the practical if it was now. (Diya)

Diya'sexpression reflected that the students were much worried about how they could secure the highest possible scores in their transcripts. However, she did not talk about how she could learn and improve her English language. Students' comments about the test system of English listening and speaking indicated that English teachers, who even did not inform students about learning and testing of listening and speaking skills, were irresponsible to their job and that the principal's interest of displaying a high score in students' certificates would have influenced teachers' teaching. Although teachers tried to defend themselves, their own contradictory language, as well as students' responses, indicated that teachers needed to be responsible to teach the English language.

\section{Discussion}

The findings suggest that private schools in the capital city have enforced their own law on the use of the English language for communication in school. Students reported a growing pressure of mandatory English-speaking on them without their intrinsic motivation. Although students' comments affirmed teachers' interest in developing students' speaking skills, the only English-speaking policy in schools, also reported in Rana (2018), Phyak (2013) and Khati (2013), was impractical in Nepali schools where the English, one of eight equal subjects, was taught as a foreign language. Teachers reported the students' frequent use of their mother tongue in communication between their friends. Students agreed that the English-speaking environment would help their learning of English but resented that the penalty for using their mother tongue for communication was against the right to speak the mother tongue. The private schools' obligation for children to communicate in English, although Nepal's Constitution, 2015 states right to education in mother tongue (Government of Nepal, 2015), not only violated children's fundamental right but also promoted hegemony over other local languages including Nepali, the national language. The private schools' English language policy, which is against the fundamental right of citizens to use their mother tongue in all communications, aligned Rana's (2018) findings that the fragile language 
policy in Nepal has provided unexpected space for the promotion of the English language regardless of learners' interest. No clear evidence was found which would support the mandatory use of English in school and develop students' speaking and listening skills. Instead, teachers, similar to the findings of Santwona Memorial Academy (2013), deliberately ignored listening and speaking skills and only taught reading and writing courses in the classroom.

The findings of four schools provide illustrative examples of how English teachers assess students' listening and speaking skills in secondary education examination board.Although the outcomes of this study may not be generalised, the findings suggest the need to reform the current system of testing students' English listening and speaking skills in schools. As discussed in previous sections, students' comments indicated that teachers graded their listening and speaking skills without formal tests, the requirement of their board examination. This resonates with the findings of Dawadi (2018) that the random assessment without a formal test of listening and speaking skills declined students' motivation for learning the skills and teachers' interest in instructional activities.Rubin et al.'s(1982) suggestion for well-organisedexamination process can make teachers responsiblefor their planning and teaching and motivate students to learn all the skills equally. Students' reported comments suggest at least two ways to systematically execute practical tests: examination board can appoint subject specialists to conduct tests in examination centres more effectively than the previous centre-based testing system or in schools, and the examiners can record interviews with students and listening tests in the hall. Otherwise, the current system of examination seems to be an unforeseen privilege for students who do not have a certain level of English language proficiency but want a high score in certificates and for teachers who are insincere to their job.

Teachers reported insufficient teaching materials for conducting the English practical activities in the classroom and the principal's force to award full marks for each student. Many of them stated that they had audio cassettes, cassette player and projector in some classrooms. However, students reported comments, such as their teachers even did not induct about English course particularly listening and speaking and awarded marks without tests, contradicted with Liu (2009) that the availability of wide range of teaching materials does not assure teachers' teaching of listening and speaking skills in the classroom and students' increasing performance. Also, teachers reported their rare use of audio cassettes for teaching listening skill. Teachers emphasised the teaching of reading and writing skills as the students had to sit written examination in different centres. This resonates the findings of Choi (2008) in Taiwan that teaching of the English language was exam-oriented rather than students' learning of the language. Awarding final score without tests seemed to have negative impacts on teaching and learning of the English language.

The findings suggest that both students and teachers have perceived the English practical exam as an essential aspect. However, teachers did not execute the standard testing system of SEE board and its impact was observed in the declining 
practice of listening and speaking skills in schools.

\section{Conclusion}

The expectation of transferring English practical tests to individual schools from the centre-based testing system might be to make schoolteachers responsible for their teaching job. However, the distribution of power to them increased random assessment without formal tests and resulted in teachers' carelessness of teaching the listening and speaking skills and reduced students' motivation for learning the skills in the classroom. The English-only for communication in schools was intended to help students forcefully learn oral skills of the English. However, this policy could not totally control students' mother tongue use between their friends. Instead, English teachers deliberately ignored the listening and speaking course of English and only focused on reading and writing activities.

The teaching of English seems to be testoriented. The teachers focused on reading and writing skills for which students had to sit an exam in different centres and less emphasised the teaching of listening and speaking skills for which teachers granted grades without formal tests. This raises issues about the validity of assessment and qualification. This suggests reforming the current system of listening and speaking tests to assure the quality of tests and validity of test score in mark sheets. Further researches in this area may explore rich information and suggest some concrete ideas to improve teaching and testing of listening and speaking skills.
Competing interests:The authors do not have any contradictory arguments in the publication of this article.

\section{References}

Ahmad, K., \& Agarwal, P. (2018). The role of CBSE ASL in enhancing the speaking and listening skills of students. Issue 8: Assessing learning (2), 13.

Alonso, R. S. (2012). The importance of teaching listening and speaking skills. (Masters thesis). Universitas Complvtensis Matritensis, Madrid. Retrieved from https:// www.ucm.es/data/cont/docs/ $\begin{array}{llllllllllllll}1 & 1 & 9 & - & 2 & 0 & 1 & 5 & - & 0 & 3 & - & 1 & 7\end{array}$ 12.RocioSeguraAlonso2013.pdf

Anderson, G., \& Arsenault, N. (2005). Fundamentals of educational research. London: Routledge.

Aryal, A., Short, M., Fan, S. F., \& Kember, D. (2016). Issues in English language teaching in Nepal. In S. Fan \& J. FieldingWells (Eds.), What is Next in Educational Research? The Netherlands: Sense Publishers.

Bista, K. (2011). Teaching English as a Foreign/Second Language in Nepal: Past and Present. English for Specific Purposes World, 11(32), 1-9. doi: https:/ / eric.ed.gov/ ?id=ED530898

Bozorgian, H. (2012). The relationship between listening and other language skills in International English Language Testing System. Theory and Practice in Language Studies, 2(4), 657-663. doi: https:/ / doi.org/ 10.4304/tpls.2.4.657-663

Broughton, G., Brumfit, C., Flavell, R., Hill, P., \& Pincas, A. (2003). Teaching English as a Foreign Language (Second ed.). London and New York: Taylor \& Francis. 
Bryman, A. (2016). Social research methods. New York: Oxford university press.

Choi, I.-C. (2008). The impact of EFL testing on EFL education in Korea. Language Testing, 25(1), 39-62. doi: https://doi.org/ $10.1177 \%$ 2F0265532207083744

Creswell, J. W. (2002). Educational research: Planning, conducting, and evaluating quantitative. Boston: Pearson.

Curriculum Development Centre. (2016). Compulsory English (Grade 9 and 10) specification grid with model questions/ curriculum development centre (CDC). Sanothimi, Bhaktapur: Author. Retrieved from http://cdclibrary.org/elibrary / pages $/$ view.php?ref $=912 \& k=$.

Dawadi, S. (2018). The Impact of the School Leaving Certificate Examination on English Language Teaching and Student Motivation to Learn English. In D. Hayes (Ed.), English Language Teaching in Nepal: Research, Reflection and Practice. (pp. 133164). Kathmandu: British Council.

Duwadi, E. P. (2018). Historical Developments in the Teaching and Learning of English in Nepal. In D. Hayes (Ed.), English Language Teaching in Nepal: Research, Reflection and Practice. Kathmandu: British Council.

Eagle, S. (1999). The Language Situation in Nepal. Journal of Multilingual and Multicultural Development, 20(4-5), 272-327. doi: $\quad$ https://doi.org/10.1080/ 01434639908666382

Eng, L. S., Mohamed, A. R., \& Javed, M. (2013). Analysis of Students 'competency in listening comprehension of the English language at Pakistani secondary school level. Middle-East journal of scientific research, 16(3), 331-341. doi: 10.5829/ idosi.mejsr.2013.16.03.2298
Giri, R. A. (2009). The politics of 'unplanning' of languages in Nepal. Journal of NELTA, 14(1), 32-44.

Giri, R. A. (2011). Languages and language politics: How invisible language politics produces visible results in Nepal. Language Problems and Language Planning, 35(3), 197221. doi: https://doi.org/10.1075/ lplp.35.3.01gir

Government of Nepal. (2015). Nepal's Constitution, 2015. Kathmandu, Nepal: Author.

Khamkhien, A. (2010). Teaching English Speaking and English Speaking Tests in the Thai Context: A Reflection from Thai Perspective. English Language Teaching, 3(1), 184-190. doi: https://doi.org/ 10.5539/elt.v3n1p184

Khati, A. R. (2011). When and why of mother tongue use in English classrooms. Journal of NELTA, 16(1-2), 42-51. doi: https:/ /doi.org/10.3126/nelta.v16i1-2.6128

Khati, A. R. (2013). Career Gains and Identity Loss: The Effects of English in the Nepali Hinterlands. Journal of NELTA, 18(12), 77-91. doi: https://doi.org/10.3126/ nelta.v18i1-2.10332

Kumar, R. (1999). Research Methodology, A step-by-step guide for beginners. London: Sage Publications, Pvt. Ltd.

Liu, T. Y. (2009). A context aware ubiquitous learning environment for language listening and speaking. Journal of Computer Assisted Learning, 25(6), 515-527. doi: https://doi.org/10.1111/j.13652729.2009.00329. $x$

Merriam, S. B., \& Tisdell, E. J. (2016). Qualitative research: A guide to design and implementation. San Francisco: John Wiley \& Sons. 
Ministry of Education. (1971). National Education System Plan, 1971 (2028 BS). His Majesty's Government of Nepal: Author.

Ministry of Education Science and Technology. (2018). Education in Figures 2017 (At A Glance). Singhdurbar, Kathmandu: Ministry of Education, Science \& Technology, Planning and Monitoring Division (Statistics, Policy and Research Section).

Patton, M. Q. (1990). Qualitative evaluation and research methods. London: SAGE Publications, inc.

Phyak, P. (2013). Language ideologies and local languages as the medium-ofinstruction policy: A critical ethnography of a multilingual school in Nepal. Current Issues in Language Planning, 14(1), 127-143. doi: https://doi.org/10.1080/ 14664208.2013.775557

Phyak, P. B. (2011). Beyond the façade of language planning for Nepalese primary education: monolingual hangover, elitism and displacement of local languages? Current Issues in Language Planning, 12(2), 265-287. doi: https://doi.org/10.1080/ 14664208.2011 .584203

Ramanathan, H. (2008). Testing of English in India: A developing concept. Language Testing, 25(1), 111-126. doi: https:// doi.org/10.1177\%2F0265532207083747

Rana, K. (2018). Retention of English language tension in multilingual communities of Nepal: A review of teachers' narratives. Journal of NELTA, 23(1-2), 40-53. doi: https://doi.org/ 10.3126/nelta.v23i1-2.23347

Richards, J. (2006). Communicative Language Teaching Today. Cambridge, New York, Melbourne, Madrid, Cape Town, Singapore, São Paulo: Cambridge University Press.
Rubin, D. L., Daly, J., McCroskey, J. C., \& Mead, N. A. (1982). A review and critique of procedures for assessing speaking and listening skills among preschool through grade twelve students. Communication Education, 31(4), 285-303.doi: https:// doi.org/10.1080/03634528209384697

Santwona Memorial Academy. (2013). A study on implementation of English listening and speaking skills. Kathmandu, Nepal: Author.

Shrestha, P. (2018). English language examination reform: International trends and a framework for Nepal. In D. Hayes (Ed.), English Language Teaching in Nepal: Research, Reflection and Practice. Kathmandu: British Council (pp. 37-57). Kathmandu: British Council.

Shrestha, R. N., Pahari, B., \& Awasti, J. R. (2014). Impact of English Language Teaching and Learning through Language Laboratory in Engineering in Nepal. Journal of the Institute of Engineering, 10(1), 94-103. doi: https://doi.org/10.3126/ jie.v10i1.10882

Smith, J. A., \& Osborn, M. (2004). Interpretative phenomenological analysis. In G. M. Breakwell (Ed.), Doing social psychology research (pp. 229-254): The British Psychological Society and Blackwell Publishing Ltd.

Sultana, N. (2018). Test review of the English public examination at the secondary level in Bangladesh. Language Testing in Asia, 8(1), 16. doi: https:// doi.org/10.1186/s40468-018-0068-1

Tavil, Z. M. (2010). Integrating listening and speaking skills to facilitate English language learners' communicative competence. Procedia-Social and Behavioral Sciences, 9, 765-770. doi: https://doi.org/ 10.1016/j.sbspro.2010.12.231 


\section{UNELTA}

Vandergrift, L., \& Goh, C. (2012). Teaching and learning second language listening: Metacognition in action. doi:https:/ / doi.org/10.4324/9780203843376

Zhang, Y. (2009). An Experimental Study of the Effects of Listening on Speaking for College Students. English Language Teaching, 2(3), 194-204. Retrieved from https://files.eric.ed.gov/fulltext/ EJ1083054.pdf

\section{Contributors:}

Kesh Rana graduated MPhil from the University of Oslo, Norway in Higher Education. He has also earned an M.Ed. from Tribhuvan University, Nepal. He has taught the English language in schools and colleges for about 15 years.

Karna Rana is an emergent researcher who has done his PhD in the field of Nepal's rural primary teachers' ICT practice in the classroom. After his Masters in English Education (M.Ed.) from Nepal, he has done his second Masters in Education (MA) from the University of Bedfordshire, England. He has taught the English language and Linguistics in Nepal for about 20 years, conducted several teacher training programmes in Nepal, presented research papers at national and international conferences. 